\title{
EXCHANGE RATES ELASTICITY OF EXPORTS IN ASEAN: THE ROLE OF GLOBAL VALUE CHAINS
}

\section{Elastisitas Ekspor Terhadap Nilai Tukar di ASEAN: Pengaruh Rantai Nilai Global}

\author{
Defy Oktaviani ${ }^{1}$, Nagendra Shrestha ${ }^{2}$ \\ ${ }^{1}$ Directorat General of International Trade Negotiation, Ministry of Trade, Republic of Indonesia, \\ M.I. Ridwan Rais Street No. 5, Jakarta 10110, Indonesia \\ ${ }^{2}$ Graduate School of International Social Science, Yokohama National University, 79-3 Tokiwadai \\ Hodogaya-ku, Yokohama-shi 240-8501, Japan \\ Email: defyoktaviani91@gmail.com
}

Naskah diterima: 12/11/2020; Naskah direvisi: 03/03/2021; Disetujui diterbitkan: 20/03/2021; Dipublikasikan online: 15/07/2021

\begin{abstract}
Abstrak
Perdebatan tentang pelemahan hubungan antara nilai tukar dan ekspor telah meningkat dalam beberapa tahun terakhir, dan meningkatnya tren perdagangan terkait rantai nilai global (Global Value Chain/GVC) diasumsikan menjadi sumber melemahnya hubungan di antara keduanya. Dengan menggunakan data spesifik industri manufaktur, studi ini bertujuan untuk menyelidiki dampak GVC pada hubungan Nilai Tukar Efektif Riil (Real Effective Exchange Rate/REER) dan ekspor di empat negara ASEAN. Estimasi dilakukan menggunakan regresi Least Square Dummy Variable (LSDV) untuk periode sampel dari tahun 2009 hingga 2015. Hasil penelitian ini menunjukkan bahwa di Filipina, koefisien elastisitas nilai tukar ekspor dan partisipasi ke GVC tidak signifikan secara statistik. Sebaliknya di Indonesia dan Malaysia, secara rata-rata, integrasi ke GVC dengan berbagai pengukuran akan menurunkan elastisitas ekspor terhadap perubahan REER sekitar 70\% sampai 89\%. Lebih lanjut, estimasi terhadap data Thailand dan kelompok empat negara ASEAN menunjukkan bahwa partisipasi pada GVC mengubah nilai dan tanda elastisitas ekspor terhadap REER.
\end{abstract}

Kata Kunci: Ekspor, Nilai Tukar, Rantai Nilai Global

\begin{abstract}
The debate on the issue of the disconnected relationship between exchange rates and exports has risen in recent years, with the growing trend of Global Value Chain (GVC)-related trade assumed to be the source of the weakening link between them. By employing manufacturing industry-specific data, this study aims to investigate the impact of GVC on the nexus of the Real Effective Exchange Rate (REER) and exports in four ASEAN countries. The estimations are conducted using Least Square Dummy Variable (LSDV) regression for the sample period from 2009 to 2015. The findings of this study suggest that for the Philippines, the coefficients of exchange rate elasticity of export and participation to GVC are not statistically significant. Conversely, in the case of Indonesia and Malaysia, integration to GVC, with various measurements, will reduce the REER elasticity of exports by around $70 \%$ to $89 \%$ on average. Furthermore, the estimation data on Thailand and a group of four countries implies that the presence of GVC changes both the value and the sign of REER elasticity of exports.
\end{abstract}

Keywords: Export, Exchange Rates, Global Value Chain

JEL Classification: F14, F15, F31 


\section{INTRODUCTION}

It has been suggested that there may be a weakened relationship between exchange rates and exports. This concern arose after the 2008 global financial crisis and some failed experiences using the exchange rate depreciation policy to increase exports. The United Kingdom depreciated its currency against the US Dollar by more than $25 \%$ in the first quarter of 2009 , but the policy did not improve the export performance (Ollivaud et al., 2015). Also, Giugliano (2015) mentioned that Japan depreciated its Yen against the US Dollar by around 20\% in 2012 with the hope of stimulating export-led growth. However, this policy also did not bring any substantial increase to Japanese exports.

Traditional model (such as the Mundell-Fleming model) may not be able to capture this weakening relationship due to its assumption regarding quality of the product, and sources of intermediate input. The theories assumed that the quality of the product in international trade is the same. Nevertheless, there are differences in product quality that make the exchange rate pass-through to export price incomplete (Mallick \& Marques, 2016).
Next, classical theories also assumed that exported products were entirely produced using domestic resources. Nonetheless, with the globalization wave, production processes across countries have become more interrelated. This trend is also supported by the fact that shares of intermediate goods trade were $50 \%$ of the total world trade in 2017 (UNCTAD, 2019 ), and the ratio increased to $62 \%$ of the total trade value in the world during 2018 (see Figure 1). An empirical study, Amiti et al. (2014), claimed that large exporters also tended to be involved in importing a large scale of intermediate inputs.

The growing number of imported intermediate goods has generated the idea that the correlation between exchange rates and exports is also influenced by Global Value Chain (GVC) (Ollivaud et al., 2015). GVC is defined as the production arrangement in which different stages of production may be done in several countries (World Bank Group et al., 2017). The existence of GVC has been widespread in recent years due to technological improvements as well as a reduction in political and trade barriers (Amador \& Cabral, 2016). 


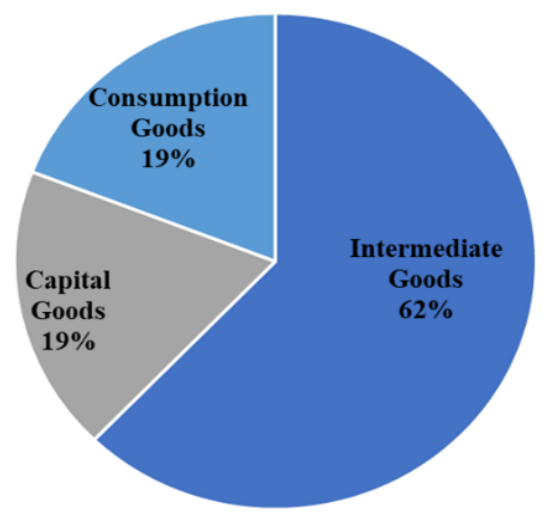

Figure 1. Shares of Intermediate Goods in World Trade in 2018

Source: UN Comtrade (2020), processed

In terms of trade statistics, the presence of GVC has weakened the analytical interpretation of conventional export and import statistics (Ahmad et al., 2017). A typical example of GVC is the production of the iPod (Dedrick et al., 2010). The products are being assembled in China, while their components are coming from many countries. Looking at the conventional trade data, it may be inferred that China has a comparative advantage in iPod production. However, the value added by Chinese workers only contributed to about $2 \%$ of the total product's price (Timmer et al., 2014).

Among the concepts of exchange rate, there is Real Effective Exchange Rate (REER) that, according to IMF (n.d.), measures the value of the domestic currency with respect to a basket of weighted-average foreign currencies divided by the price index. REER describes the competitiveness of a currency in the international market. An increase in REER means appreciation of exchange rates while a fall in this index means depreciation (Krugman et al., 2015).

In standard macroeconomics theory, change in the exchange rate will influence exports through the expenditure-switching mechanism (Obstfeld \& Rogoff, 2007). This means that when there is depreciation, the price of exported goods will be more competitive; therefore, demand from abroad increases. The magnitude of change in export volume due to the change in the exchange rate is reflected in the exchange rate elasticity of exports (Krugman et al., 2015). Since this study uses REER to represent the exchange rates, the term exchange rate elasticity of exports and REER elasticity of exports can be used interchangeably.

GVC increases the interconnectedness of global production in the form of forward or backward linkage. Forward linkage means that a country produces goods that can be exported as intermediate inputs to other countries. On the other hand, backward linkage means that the nation uses intermediate inputs originating from 
abroad when producing exported goods. According to de Soyres et al. (2018), the presence of foreign components in production, through forward and backward linkage, explains why the sensitivity of export volume to the exchange rates' appreciation or depreciation is affected by participation to GVC. It has been predicted that the higher a country's participation in GVC, the lower its exchange rate elasticity of exports.

Some empirical works have been carried out to investigate the impact of GVC participation on exchange rate elasticity of exports. While Leigh et al. (2015) argued that there was no clear evidence on the disconnected relationship between exchange rate and exports in 60 countries, other scholars have proved the argument of weakening exchange rate elasticity of exports. Ahmed et al. (2016) found empirical evidence from 46 countries that the exchange rate elasticity of exports decreased over time, and the effect of change in REER on exports reduced by $22 \%$ with the presence of GVC. Moreover, working with Switzerland's export data, Fauceglia et al. (2018) confirmed that backward linkage GVC dampened the negative effect of exchange rate appreciation to export value.

Some researchers also have tested the impact of GVC on the relationship between exchange rates and exports, particularly in Asia, and they found various results. Sato et al. (2016) found that exchange rate instability negatively and significantly influences trade as a whole and particularly in electrical machinery industries. However, the impact was not significant for other machinery sectors. The researchers speculated that growing fragmentations in the production process had weakened the effect of exchange rate changes on regional trade in Asia. Furthermore, Bang \& Park (2018) proved that participation in GVC decreased the exchange rate elasticity of exports in South Korea by $33 \%$. However, the effect was not statistically significant for Japan and China.

The empirical model in the previous study used a linear regression. The model set the volume of exports as the independent variable and the exchange rate, GVC measurement, as well as the interaction of GVC with the exchange rate as the independent variables. Nonetheless, since the 
concept of the relationship between GVC and exchange rate elasticity is quite new, the empirical strategy to observe it still diverges and may account for the differences in the results of the study. There were some differences in the proxy of the main independent variables and the method to estimate the model.

First, previous studies have used different proxies for exchange rate variable and GVC measurement. Leigh et al. (2015) and Ahmed, et al. (2016) used REER data at the aggregate level from IMF, which is computed using CPI as the deflator, as the proxy for the exchange rate variable. However, Sato et al. (2016) and Bang \& Park (2018) used industry-specific REER, since there was heterogeneity in each industry. It has been argued that utilizing aggregate data may cause bias in the estimation. Regarding the GVC measurement, aside from the GVC participation index by Koopman et al.'s (2014) method, Cheng et al. (2016) and Tan et al. (2019) used the share of foreign value-added to total gross exports as a proxy for GVC.

Second, data used in the previous studies were panel data, and the methods used to estimate were both static and dynamic panel estimation. To handle the unobserved heterogeneity, Cheng et al. (2016) and Bang \& Park (2018) used the Fixed Effects Model or Least Square Dummy Variable method to estimate the effects of GVC on exchange rate elasticity. Then, due to the possible two-way causalities between trade volume and exchange rate, the model panel with lags was employed. To illustrate, Bang \& Park (2018) used the System Generalized Method of Moments (System GMM) in the robustness check, and Leigh et al. (2015) estimated the model using the Autoregressive Distributed Lags (ARDL) model, since they included lags of the dependent and some independent variables. In addition, Ahmed, Appendino, and Ruta (2016) used the White cross-section covariance method to deal with heteroscedasticity problems. 


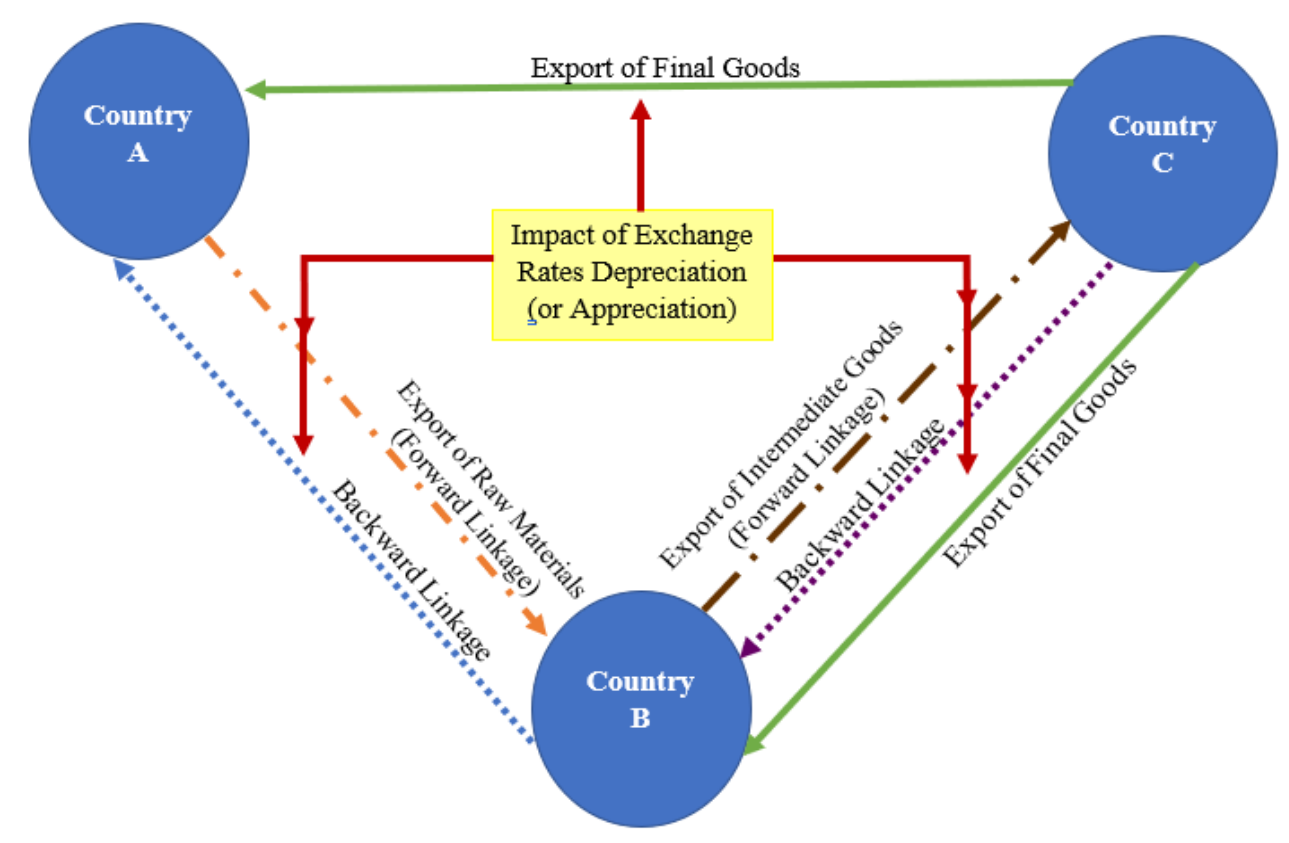

\section{Figure 2. Exchange Rates and Exports in The GVC Framework}

Source: de Soyres et al. (2018), modified

Most previous studies have chosen countries in Europe or East Asia as the sample, because those countries have advanced production linkage and actively take part in GVC. The growing trend of ASEAN countries' participation in GVC makes it interesting to investigate the impact of GVC in this region. ASEAN commits to improving its contribution to GVC, which is included in the ASEAN Economic Community (AEC) Blueprint 2025 (ASEAN Secretariat, 2019). In addition, ASEAN was the second most involved region in GVC after the European Union (ASEANJapan Centre, 2017a). This study will contribute to the current literature by adding empirical evidence of the effect of GVC on exchange rate elasticity of exports specialized in the cases of ASEAN countries.

Now, for the case of ASEAN, empirical studies on the effect of GVC to the nexus of the exchange rate and exports have been conducted by Cheng et al. (2016) and Tan et al. (2019). Cheng et al. (2016) found that the higher the level of GVC participation, the lower the export sensitivity to changes in exchange rates. Therefore, attaining a certain level of trade balance may require a more substantial depreciation of exchange rates. On the other hand, Tan et al. (2019) focused on the impact of GVC on exchange rate volatility, not on exchange rate elasticity. It has been proven that GVC could lower the negative effect of exchange rate 
volatility on exports by $75 \%$. Their study found a similar result with Sato \& Zhang (2019) that participation in GVC could lessen the negative impact of exchange rate volatility to export.

However, previous studies in ASEAN were conducted by using country-level data in their analysis. Neither has considered the possibility of sectoral heterogeneity nor used industry-specific data, as mentioned in Bang \& Park's (2018) study.

Even though this study attempts to examine this issue in ASEAN, it does not use all ASEAN countries as the object of observations. Referring to Figure 3 , Singapore contributed $36 \%$ of total ASEAN exports in 2015, the highest among 10 ASEAN members. Conversely, Brunei Darussalam, Cambodia, Lao PDR, and Myanmar had a relatively small share of exports. Hence, those five countries are excluded from this research. One of the reasons for excluding Singapore from this study is because the country has different economic structure than other ASEAN Member States. Singapore is a services-oriented country which $80 \%$ of its value added comes from services sector and it has a very tiny fraction of primary sector (ASEAN-Japan Centre, 2018).
Furthermore, Thailand, Malaysia, Indonesia, Vietnam, and the Philippines had quite similar characteristics and contributed about $5 \%$ to $20 \%$ of ASEAN exports. However, due to data limitations, this study excludes Vietnam from the sample. Accordingly, Thailand, Malaysia, Indonesia, and the Philippines are the sample for this research.
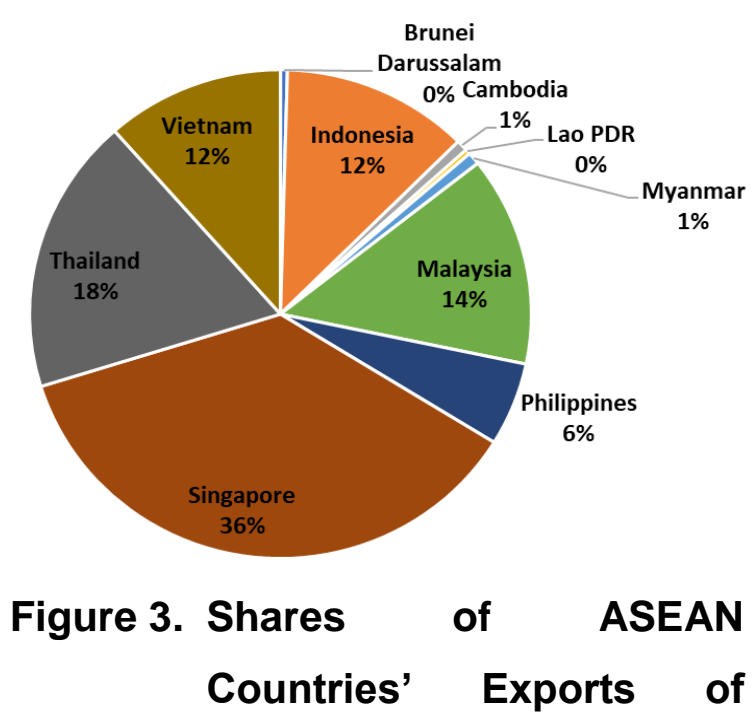
Goods \& Services in 2015

Source: World Bank (2020), processed

By employing industry-specific data, this study will examine whether GVC affects the elasticity of exports with respect to exchange rate movement in four ASEAN countries. To achieve the objective, two specific steps will be carried out. First, the exchange rate elasticity of exports should be measured. Second, we need to calculate whether integration with GVC lowers exports' sensitivity to exchange rate depreciation. 
METHOD

\section{GVC Measurement}

Various approaches have been proposed to measure GVC participation. Amador \& Cabral (2016) highlighted that there are three approaches to calculate the involvement in GVC. The first approach is using the data of trade in parts and components. The second alternative is by utilizing customs statistics on processing trade, which is highly disaggregated. The third approach makes use of the Input-Output (I-O) table to gauge GVC participation.

Currently, the most widely used method for calculating GVC integration is utilizing the $\mathrm{I}-\mathrm{O}$ table. $\mathrm{I}-\mathrm{O}$ based measurements allow us to track valueadded from every phase of the manufacturing process. Among researchers who utilized $\mathrm{I}-\mathrm{O}$ table to measure GVC, Koopman et al. (2014) proposed a framework to decompose gross export into value-added export.

The rows in the I-O table show the use of the gross output from industry in a nation, and the columns represent the number of intermediates needed for the production side. Therefore, each column contains information on domestic and foreign share in intermediate inputs used in the production of output (UNCTAD, 2013). Suppose there are $N$ countries and $M$ industries; then, the I-O table can be written into matrix form as: $\mathbf{X}=\mathbf{Z u}+\mathbf{Y}$

where $\mathbf{X}$ is a $(N M \times 1)$ vector for total output, $\mathbf{Z}$ is a $(N M \times N M)$ matrix of intermediate input transactions, $\mathbf{Y}$ is a $(N M \times 1)$ vector of final demand, and $\mathbf{u}$ is a $(N M \times 1)$ vector of ones.

Next, define a $(N M \times N M)$ block matrix $\mathbf{A}=\mathbf{Z} \widehat{\mathbf{X}}^{-1}$ (where $\widehat{\mathbf{X}}$ is a diagonal matrix of gross output vector $\mathbf{X}$ ) such that each column represents the input coefficients needed to produce a single unit of output of an industry denoted by that column. Mathematically, equation (1) can be rearranged as:

$$
\begin{aligned}
& \mathbf{X}=\mathbf{A X}+\mathbf{Y} \\
& (\mathbf{I}-\mathbf{A}) \mathbf{X}=\mathbf{Y} \\
& \mathbf{X}=(\mathbf{I}-\mathbf{A})^{-\mathbf{1}} \mathbf{Y}=\mathbf{B Y} .
\end{aligned}
$$

where $\mathbf{B}$ is a Leontief inverse matrix of size $(N M \times N M)$.

The I-O framework can be used to calculate the value-added exports or $\mathbf{T}$ matrix (UNCTAD, 2013). In decomposing gross exports into valueadded exports, it is vital to calculate the value-added coefficient (V), which is defined as the shares of value-added per one unit of output produced from a specific industry in a country. Then, gross export (E) is the total of exported intermediate goods and final goods. Hence, value-added exports can be 
calculated by combining the (B ) and diagonalized gross export diagonalized value-added coefficient vector.

vector with a Leontief inverse matrix $\quad \mathbf{T}=\widehat{\mathbf{V}} * \mathbf{B} * \widehat{\mathbf{E}}$

$\left[\begin{array}{ccc}T^{11} & \cdots & T^{1 n} \\ \vdots & \ddots & \vdots \\ T^{n 1} & \cdots & T^{n n}\end{array}\right]=\left[\begin{array}{ccc}V^{1} & 0 & 0 \\ 0 & \ddots & 0 \\ 0 & 0 & V^{n}\end{array}\right]\left[\begin{array}{ccc}B^{11} & \cdots & B^{1 n} \\ \vdots & \ddots & \vdots \\ B^{n 1} & \cdots & B^{n n}\end{array}\right]\left[\begin{array}{ccc}E^{1} & 0 & 0 \\ 0 & \ddots & 0 \\ 0 & 0 & E^{n}\end{array}\right]$

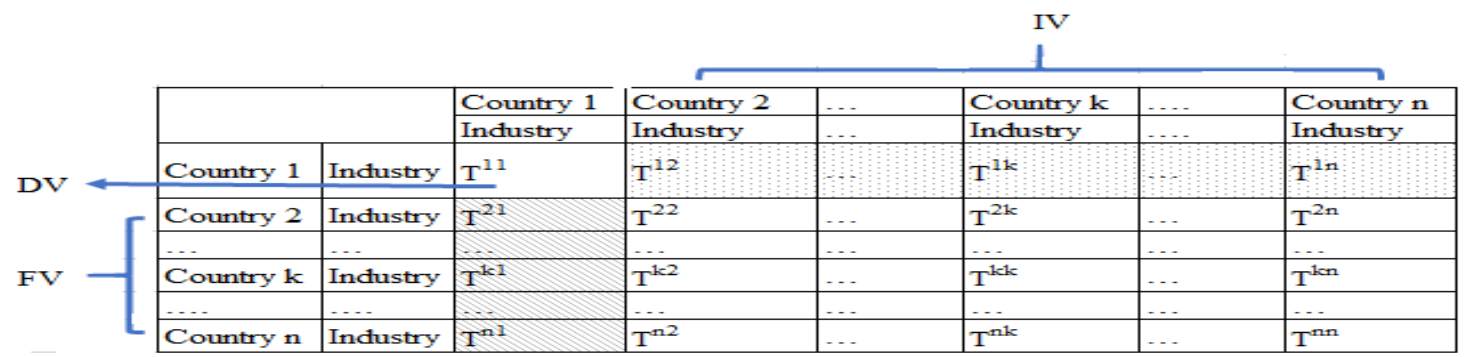

Figure 4. Value-Added Contents of Gross Exports of Country 1

Source: UNCTAD (2013), modified

The T matrix, which has $N M \times N M$ dimension, contains three elements of value-added exports (UNCTAD, 2013; Aslam et al., 2017). First, Domestic Value-Added (DV) lies in each of the diagonal parts of the matrix. Second, Foreign Value-Added (FV) is defined as the sum of all elements in each column, excluding the diagonal element of the matrix. Lastly, Indirect Value-Added (IV) or domestic value-added used as intermediate inputs in other countries can be computed by summing all elements in each row subtracted by the elements of the diagonal matrix. In a country-sector framework, the matrix of value-added exports can be represented in Figure 4.

After decomposing gross exports into value-added exports, according to Koopman et al. (2010) and Koopman et al. (2014), two indices describing the level of integration in GVC can be estimated:

a. GVC participation index

GVC participation index $=\frac{I V}{X}+\frac{F V}{X}$...

Where $X$ is gross exports, $I V$ is indirect value-added, and $F V$ represents foreign value-added. The first part of the index measures forward linkage, while the second part describes the backward 
linkage of exported goods production in a global framework. By using export as the weight, the formula has controlled the size effect of each economy.

b. GVC position index

GVC position index $=\ln \left(1+\frac{I V}{X}\right)-$

$\ln \left(1+\frac{F V}{X}\right)$
This index represents countries' positions in GVC. If a country supplies parts or components to be assembled in other countries, it means that country lies in the upstream part of GVC, and the index will be positive. Conversely, if a country lies in the downstream part of GVC or the assembly process, then the position index will have a negative sign.

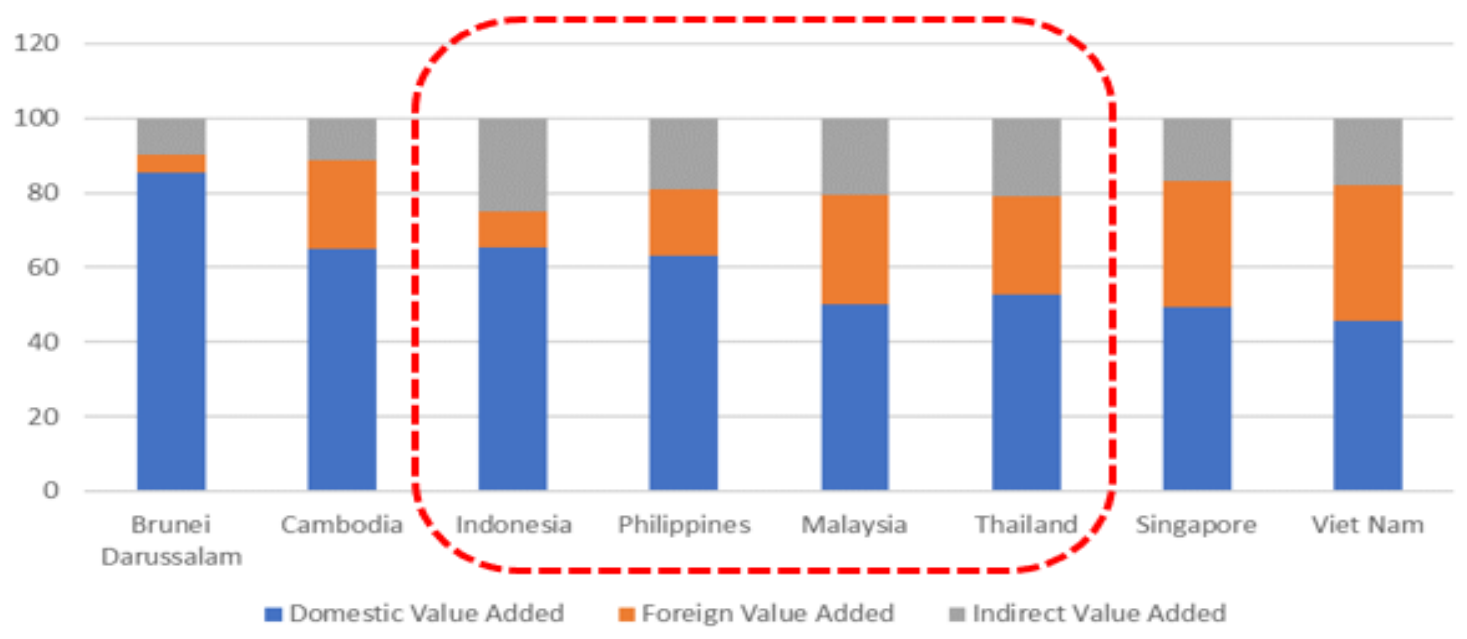

Figure 5. Domestic, Foreign, and Indirect Value-Added of ASEAN's Gross Exports in 2015 (in Percentage)

Source: OECD TiVA Database (2020), processed

\section{Empirical Method}

This research is a cross-country study using four ASEAN countries, namely Indonesia, Malaysia, Thailand, and the Philippines. Even though only four countries represent the ASEAN in this research, they contribute $50 \%$ of the exports of goods and services. Furthermore, Figure 5 reveals that Indonesia and the Philippines, as well as
Malaysia and Thailand, have similar compositions of domestic value-added, foreign value-added, and indirect value-added contents of gross exports. In addition, the sample periods of this study are from 2009 to 2015. Although data is available from 2005 to 2015 , the chosen period eliminates the shock due to the global financial crisis in 2008. 
To test the effects of GVC on exchange rate elasticity of exports, this study employed empirical model previously used in Bang \& Park (2018) research. However, to avoid the possibility of endogeneity bias, lagged values of independent variables are utilized in the regression (Tan et al., 2019). The empirical model specification is as follows:

$$
\begin{aligned}
\Delta \ln X_{s, t}{ }^{c}= & \alpha+\beta \Delta \ln R E E R_{s, t-1}{ }^{c}+ \\
& \gamma \Delta \ln Y_{s, t-1}{ }^{c}+\delta \ln Q_{s, t-1}{ }^{c}+ \\
& \theta G V C_{s, t-1}{ }^{c}+\tau \Delta \ln R E E R_{s, t-1}{ }^{c} \times \\
& G V C_{s, t-1}{ }^{c}+\lambda_{s}{ }^{c}+\lambda_{t}{ }^{c}+\epsilon_{s, t}{ }^{c} \ldots(
\end{aligned}
$$

Where $c, s$, and $t$ denote country, industry, and time, respectively, $X$ represents export volume, REER is the industry-specific real effective exchange rate, $Y$ is foreign output, $Q$ represents real output from the manufacturing sector as the proxy of initial production, $G V C$ is the level of integration to GVC, $\lambda_{s}{ }^{c}$ is industry-specific fixed effect, $\lambda_{t}{ }^{c}$ is year fixed effect, and $\epsilon_{s, t}{ }^{c}$ symbolize error term. Lastly, $\alpha, \beta, \gamma, \delta, \theta, \mu$, and $\tau$ are the parameters.

The equation (7) will be estimated for each country and a group of four countries using the Least Square Dummy Variable (LSDV) estimation. The utilization of LSDV can control timeinvariant variables by using industry and time fixed effects (Soejachmoen, 2016).
Furthermore, for the GVC variable, this study will use three different proxies. The first two are the GVC participation index and position index developed by Koopman, Wang, \& Wei (2014). The other proxy refers to Tan et al.'s (2019) study by using the ratio of foreign valueadded to gross exports.

By using the confidence levels $1 \%$, $5 \%$, and $10 \%$, this estimation is interested in examining the value of parameters $\beta$ and $\tau$. If there were no interaction term between exchange rate and GVC, parameter $\beta$ will represent REER elasticity of exports, and the value is expected to be negative. This means that a $1 \%$ decrease in REER(depreciation) will increase exports by $\beta \%$, and vice versa. However, in equation (7), there is an interaction term of GVC and the exchange rate variable, so that the exchange rate elasticity of exports is no longer $\beta$. The marginal effect is calculated as:

$$
\frac{\partial(\Delta \ln X)}{\partial(\Delta \ln R E E R)}=\beta+(\tau * G V C)
$$

Based on equation (8), the magnitude of REER elasticity of exports depends on the value of GVC variable. According to Williams (2015), since both variables in the interaction term are continuous, we need to center the value 
of GVC variable around its mean.

Parameter $\tau$ is expected to have a positive sign, the opposite sign of $\beta$, indicating that the existence of GVC reduces REER elasticity of export.

The level of data is at the industry level based on the 2-digit ISIC Rev.4 classification. Industry-level data are preferable to aggregate-level data to avoid bias due to heterogeneity in each sector. Several previous studies have also used an industry-level analysis, such as Sato et al. (2016) and Bang \& Park (2018). Industry classification at the 2-digit ISIC Rev.4 was chosen based on the availability of data in the Inter-Country Input-Output (ICIO) tables (OECD, 2018b). This study will focus on 13 manufacturing sectors. The classification of manufacturing sectors refers to Sato et al. (2015) with adjustments to the latest ISIC Rev.4 (Table 1).

\section{Table 1. Manufacturing Sector Classifications}

\begin{tabular}{|c|c|c|c|c|}
\hline No. & $\begin{array}{l}\text { HS Code } \\
\text { (2-Digit) }\end{array}$ & ISIC Rev.4 & Sector Name & Sector Description \\
\hline 1 & $02-05,07-24,35,41$ & $10-12$ & Food & $\begin{array}{l}\text { Food products, beverages, and } \\
\text { tobacco }\end{array}$ \\
\hline 2 & $\begin{array}{l}41-43,50-66,70,88, \\
91,94,96\end{array}$ & $13-15$ & Textile & $\begin{array}{l}\text { Textiles, wearing apparel, leather, } \\
\text { and related products }\end{array}$ \\
\hline 3 & $44-46,64$ & 16 & Wood & Wood and products of wood and cork \\
\hline 4 & $\begin{array}{l}47-49,56,59,84-85, \\
96\end{array}$ & $17-18$ & Paper & Paper products and printing \\
\hline 5 & 27 & 19 & Petroleum & Coke and refined petroleum products \\
\hline 6 & $\begin{array}{l}15,22,26-40,44,54- \\
55,84\end{array}$ & $20-21$ & Chemical & $\begin{array}{l}\text { Chemicals and pharmaceutical } \\
\text { products }\end{array}$ \\
\hline 7 & $39-40,59,65,85,94$ & 22 & Rubber & Rubber and plastic products \\
\hline 8 & $\begin{array}{l}25,27,38,68-71,85, \\
94\end{array}$ & 23 & Non-Metal & Other non-metallic mineral products \\
\hline 9 & $\begin{array}{l}26,71-76,78-85,89, \\
93-94\end{array}$ & $24-25$ & Metal & $\begin{array}{l}\text { Basic Metals and Fabricated Metal } \\
\text { Products }\end{array}$ \\
\hline 10 & $73,84-85,87-88,95$ & 28 & $\begin{array}{l}\text { General } \\
\text { Machinery }\end{array}$ & Machinery and equipment, n.e.c. \\
\hline 11 & $\begin{array}{l}63,73-74,84-85,90, \\
94\end{array}$ & 27 & $\begin{array}{l}\text { Electrical } \\
\text { Equipment }\end{array}$ & Electrical equipment \\
\hline 12 & $84-85,90-91,95$ & 26 & $\begin{array}{l}\text { Optical } \\
\text { Instruments }\end{array}$ & $\begin{array}{l}\text { Computer, electronic and optical } \\
\text { products }\end{array}$ \\
\hline 13 & 84-89, 94 & $29-30$ & $\begin{array}{l}\text { Transport } \\
\text { Equipment }\end{array}$ & $\begin{array}{l}\text { Motor vehicles, trailers and semi- } \\
\text { trailers, and other transport } \\
\text { equipment }\end{array}$ \\
\hline
\end{tabular}

Source: Sato et al. (2015), modified

Note: *) Explanation of HS 2-digit classification can be accessed from UN Trade Statistics (2020) through the link: https://unstats.un.org/unsd/tradekb/Knowledgebase/50018/HarmonizedCommodity-Description-and-Coding-Systems-HS

${ }^{* *}$ ) Detailed classification of ISIC Rev.4 can be retrieved from United Nations Statistics Division (n.d.) through the link: https://unstats.un.org/unsd/classifications/Econ/Download/In\%20Text/ISIC Rev 4 publicati on English.pdf 
This study will be conducted using various data sources. Data on export volume were retrieved from Trade Map and UN Comtrade at the 6-digit level of the Harmonized System (HS). To convert the export data at the product level (6-digit of HS) to industry level (2digit of ISIC Rev.4), we used the concordance table developed by the OECD (2018a). Data of industry-specific Real Effective Exchange Rate (I-REER) were retrieved from the Research Institute of Economy, Trade, and Industry (RIETI) database (RIETI, n.d.). The available data is at the monthly level; hence, a simple average was used to convert it to annual data.

In addition, the Producer Price Index (PPI) data were retrieved from the CEIC Data and other national statistics, such as Bank Indonesia. Since the weights for the PPI calculation were unavailable, the monthly and quarterly data was converted into annual level by using simple average.

Unlike Bang \& Park's (2018) study that used data from the WIOD to compute GVC participation, this study utilized data from the $\mathrm{ICIO}$ tables from the OECD (2018b). This choice was made because only the Indonesian input-output table was available in
WIOD while the other three ASEAN countries' data were not provided. The ICIO table was also used to calculate the foreign and sectoral output data.

\section{RESULTS AND DISCUSSION}

\section{Indonesia}

Table 2 summarizes the regression results for Indonesia. Since there is a heteroscedasticity problem, this regression was conducted using robust standard error.

As presented in Table 2, the estimated coefficients on the lagged value of industry-specific REER are negative and significant at the $5 \%$ and $10 \%$ levels of confidence only in columns (1) and (3), respectively. In those estimations, lagged GVC participation index or lagged foreign value-added shares and its interaction term are included in the model. The sign is consistent with the theory, implying that depreciation of the exchange rate may lead to an increase in exports, and vice versa. According to Figure 5, the shares of domestic value-added in Indonesian exports was more than $60 \%$. Therefore, when the exchange rate depreciates, the price of Indonesian exports in the foreign market will be lower. Consequently, the demand for exports will increase. 
Table 2. Regression Results for Indonesia

\begin{tabular}{|c|c|c|c|}
\hline $\begin{array}{l}\text { Dependent Variable: Export } \\
\text { Volume }\end{array}$ & $\begin{array}{c}(1) \\
\text { With GVC } \\
\text { participation index }\end{array}$ & $\begin{array}{c}\text { (2) } \\
\text { With GVC } \\
\text { position index }\end{array}$ & $\begin{array}{c}(3) \\
\text { With foreign value } \\
\text { added shares }\end{array}$ \\
\hline Lagged Industry-Specific & $-1.4460^{* *}$ & 0.0478 & $-1.5456^{*}$ \\
\hline REER & {$[0.6175]$} & {$[0.30757]$} & {$[0.8058]$} \\
\hline Lagged Foreign Output & $\begin{array}{l}-0.2820 \\
{[0.3909]}\end{array}$ & $\begin{array}{l}-0.4326 \\
{[0.4178]}\end{array}$ & $\begin{array}{l}-0.8899^{* *} \\
{[0.4211]}\end{array}$ \\
\hline Lagged Real Output & $\begin{array}{l}0.3985^{*} \\
{[0.2209]}\end{array}$ & $\begin{array}{c}0.2606 \\
{[0.2357]}\end{array}$ & $\begin{array}{l}0.3991^{*} \\
{[0.2229]}\end{array}$ \\
\hline Lagged GVC Participation & -0.6614 & & \\
\hline Index & [1.0227] & & \\
\hline Interaction between Lagged & $3.1794^{* \star \star}$ & & \\
\hline $\begin{array}{l}\text { REER and Lagged GVC } \\
\text { Participation Index }\end{array}$ & [1.1268] & & \\
\hline Lagged GVC Position Index & & $\begin{array}{c}1.2059 \\
{[1.0478]}\end{array}$ & \\
\hline Interaction between Lagged & & 0.0855 & \\
\hline REER and Lagged GVC & & [1.6414] & \\
\hline $\begin{array}{l}\text { Position Index } \\
\text { Lagqed Foreign Value Added }\end{array}$ & & & -1.9006 \\
\hline (FVA) & & & [1.3335] \\
\hline Interaction between Lagged & & & $6.7276^{\star \star}$ \\
\hline REER and Lagged FVA & & & [2.9880] \\
\hline Constant & $\begin{array}{l}-2.7648^{*} \\
{[1.6170]}\end{array}$ & $\begin{array}{c}-1.7878 \\
{[1.7307]}\end{array}$ & $\begin{array}{l}-2.6160 \\
{[1.6375]}\end{array}$ \\
\hline Industry Fixed Effects & Yes & Yes & Yes \\
\hline Year Fixed Effects & Yes & Yes & Yes \\
\hline Observations & 78 & 78 & 78 \\
\hline R-squared & 0.3308 & 0.2975 & 0.3435 \\
\hline
\end{tabular}

Heteroscedasticity robust standard errors in brackets

${ }^{*} p<0.10,{ }^{* *} p<0.05,{ }^{* * *} p<0.01$

The results show that interaction terms of REER and GVC in three cases have a positive sign. However, they are statistically significant only in columns (1) and (3). This implies, in those cases, that Indonesia's participation in the Global Value Chain affects its exchange rate elasticity of exports. The mean value of Indonesia's GVC participation index from 2009 to 2015 is 0.3643 (in Table 3).

By looking at the result of column (1), the estimated coefficient of lagged REER is -1.4460 and the estimated coefficient on the interaction term is 3.1794. Since it is known that the average value of GVC participation index is 0.3643 , then, by using formula (8) the estimated REER elasticity of exports can be calculated as $-1.4460+$ $(3.1794 \times 0.3643)=-0.2877$. We can also conclude that participation in GVC will lower the elasticity of exports to REER by $80.10 \%$. The figure is obtained by calculating percentage change of estimated coefficient of lagged REER and the estimated REER elasticity of exports. 
Similarly, by examining column (3), the estimated REER elasticity of exports in Indonesia is -0.1738 . This means that the elasticity will lower by $88.75 \%$ when integration to GVC is represented by the foreign components' shares to gross exports.

Additionally, the average GVC position index for Indonesia is -0.0421 , indicating that, on average, Indonesia's manufacturing industry lies in the downstream part of GVC. Nevertheless, the GVC position index is not significantly affecting the exchange rate elasticity of exports. This finding shows a consistent result with a previous study conducted by Ahmed et al. (2016) and Bang \& Park (2018).

\section{Table 3. The Average Value of GVC Integration Variables}

\begin{tabular}{cllr}
\hline Country & \multicolumn{1}{c}{ Types of GVC Variables } & $\begin{array}{c}\text { No. of } \\
\text { Observations }\end{array}$ & \multicolumn{1}{c}{ Mean } \\
& \multicolumn{1}{c}{ Indonesia } & 91 & 0.3643 \\
\cline { 2 - 4 } & GVC participation index & 91 & -0.0421 \\
\cline { 2 - 4 } Malaysia & Foreign value-added shares to gross export & 91 & 0.2039 \\
\cline { 2 - 4 } & GVC participation index & 91 & 0.4956 \\
\cline { 2 - 4 } & GVC position index & 91 & -0.2167 \\
\cline { 2 - 4 } Philippines & Foreign value-added shares to gross export & 91 & 0.3837 \\
\cline { 2 - 4 } & GVC participation index & 91 & 0.4558 \\
\cline { 2 - 4 } Thailand position index & Foreign value-added shares to gross export & 91 & -0.0596 \\
\hline \multirow{3}{*}{ 4 ASEAN } & GVC participation index & 91 & 0.2623 \\
\cline { 2 - 4 } & GVC position index & 91 & 0.5004 \\
\cline { 2 - 4 } Countries & GVC participation index & 91 & -0.2375 \\
\cline { 2 - 4 } & GVC position index & 91 & 0.4001 \\
\cline { 2 - 4 } & Foreign value-added shares to gross export & 364 & -0.13840 \\
\hline
\end{tabular}

Source: Author's calculation

\section{Malaysia}

The regression result for Malaysia (Table 4) shows that the estimated coefficient on lagged REER is positive and statistically significant in all estimations. The positive sign is not consistent with the theory. This means that ceteris paribus, the export volume will decline if there is a depreciation in exchange rates, and vice versa. The positive signs may have a connection with the decomposition of value-added exports in Figure 5. The shares of foreign intermediate input in Malaysian exports are quite high (approximately $30 \%$ ). Hence, the depreciation of the exchange rate can raise the cost of production and the price of exported goods. Eventually, it may decrease the demand for exports. 


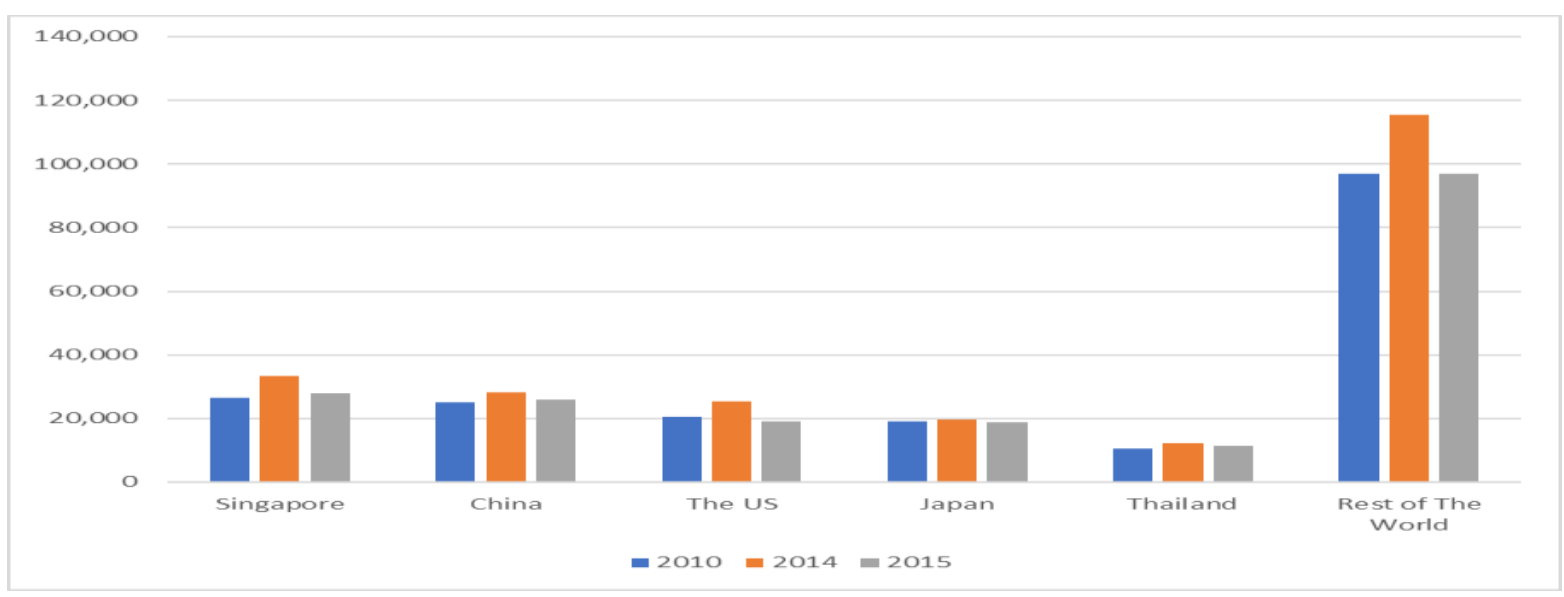

Figure 6. Export value from Malaysia to its Major Partners (in USD Millions)

Source: WITS data (2020), processed

Previous empirical studies support the analysis above. Abeysinghe and Yeok (1998) found that in Singapore's case, in the presence of high import contents, exports were not adversely affected by exchange rate appreciation. Kang \& Dagli (2018) found that in 72 economies, the Real Exchange Rate (RER) elasticity of export was dampened after the global financial crisis. Even the coefficient of lagged RER showed an opposite sign to the theory. One of the structural factors that influence this result is deepening GVCs.

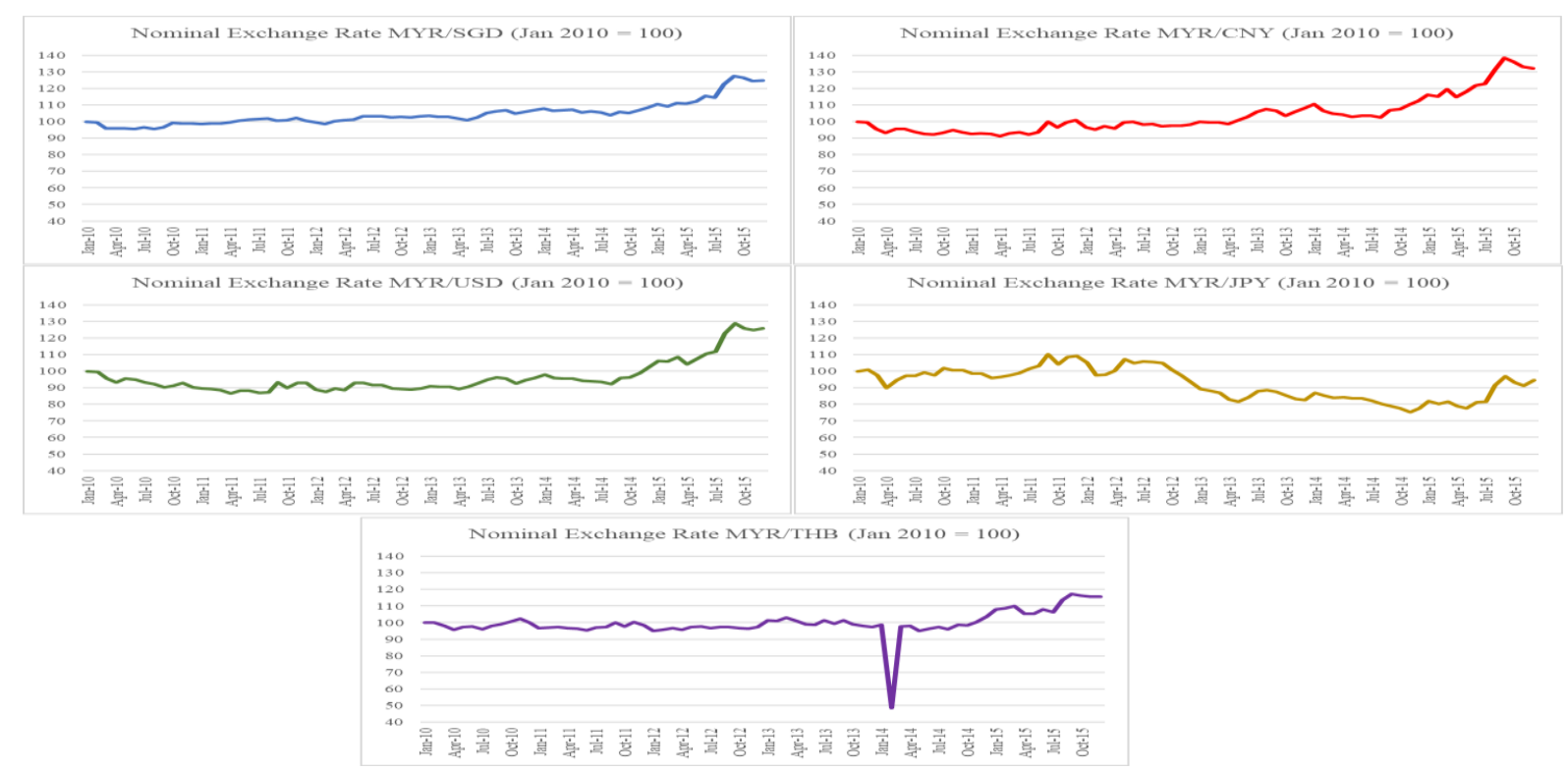

Figure 7. Bilateral Exchange Rates Between Malaysia and its Major Partners (2010 - 2015)

Source: Investing.com (2020), processed 
The positive sign of exchange rates coefficients can also be explained by the bilateral trade data between Malaysia and its major partners. Figure 6 reveals, between 2010 and 2015, there are five major destinations of Malaysian exports, namely Singapore, China, the United States, Japan, and Thailand. Looking together at Figure 6 and Figure 7, the bilateral export values between Malaysia and the US, as well as Malaysia and Japan increased from 2010 to 2014 although their bilateral nominal exchange rates appreciated. Conversely, export between Malaysia and its major partners declined despite the depreciation of bilateral nominal exchange rates in 2015.

\section{Table 4. Regression Results for Malaysia}

\begin{tabular}{|c|c|c|c|}
\hline Dependent Variable: Export Volume & $\begin{array}{c}\text { (1) } \\
\text { With GVC } \\
\text { participation } \\
\text { index }\end{array}$ & $\begin{array}{c}\text { (2) } \\
\text { With GVC } \\
\text { position } \\
\text { Index }\end{array}$ & $\begin{array}{c}(3) \\
\text { With foreign } \\
\text { value-added } \\
\text { shares }\end{array}$ \\
\hline Lagged Industry-Specific REER & $\begin{array}{l}4.8299^{* *} \\
{[1.9655]}\end{array}$ & $\begin{array}{l}5.8666^{* *} \\
{[2.2965]}\end{array}$ & $\begin{array}{l}6.4375^{* *} \\
{[2.4576]}\end{array}$ \\
\hline Lagged Foreign Output & $\begin{array}{l}2.7909^{* * *} \\
{[0.8692]}\end{array}$ & $\begin{array}{l}3.1967^{\star \star *} \\
{[0.9167]}\end{array}$ & $\begin{array}{l}3.0346^{* \star *} \\
{[0.8565]}\end{array}$ \\
\hline Lagged Real Output & $\begin{array}{l}-0.3754 \\
{[0.3294]}\end{array}$ & $\begin{array}{l}-0.1377 \\
{[0.4776]}\end{array}$ & $\begin{array}{l}-0.3039 \\
{[0.4388]}\end{array}$ \\
\hline Lagged GVC Participation Index & $\begin{array}{l}-1.1552 \\
{[2.8323]}\end{array}$ & & \\
\hline $\begin{array}{l}\text { Interaction between Lagged REER and } \\
\text { Lagged GVC Participation Index }\end{array}$ & $\begin{array}{l}-8.5893^{*} \\
{[4.3503]}\end{array}$ & & \\
\hline Lagged GVC Position Index & & $\begin{array}{l}-2.3809 \\
{[1.9363]}\end{array}$ & \\
\hline $\begin{array}{l}\text { Interaction between Lagged REER and } \\
\text { Lagaed GVC Position Index }\end{array}$ & & $\begin{array}{l}19.1355^{\star *} \\
{[8.81071}\end{array}$ & \\
\hline Lagged Foreign Value Added (FVA) & & & $\begin{array}{c}1.2999 \\
{[3.0099]}\end{array}$ \\
\hline $\begin{array}{l}\text { Interaction between Lagged REER and } \\
\text { Lagged FVA }\end{array}$ & & & $\begin{array}{l}-14.9385^{* *} \\
{[6.6490]}\end{array}$ \\
\hline Constant & $\begin{array}{c}2.6249 \\
{[2.0078]}\end{array}$ & $\begin{array}{c}0.2965 \\
{[3.2501]}\end{array}$ & $\begin{array}{c}1.4858 \\
{[3.2892]}\end{array}$ \\
\hline Industry Fixed Effects & Yes & Yes & Yes \\
\hline Year Fixed Effects & Yes & Yes & Yes \\
\hline $\begin{array}{l}\text { Observations } \\
\text { R-squared }\end{array}$ & $\begin{array}{c}78 \\
0.3825 \\
\end{array}$ & $\begin{array}{c}78 \\
0.4150\end{array}$ & $\begin{array}{c}78 \\
0.4157\end{array}$ \\
\hline
\end{tabular}

Heteroscedasticity robust standard errors in brackets ${ }^{*} p<0.10,{ }^{* *} p<0.05,{ }^{* * *} p<0.01$

Regarding integration in GVC, the interaction terms in all cases are also statistically significant and suggests that engagement in GVC has an impact on the REER elasticity of exports in Malaysia. The values of the coefficient of interaction term of GVC variables and exchange rate in columns (1) and (3) 
have a negative sign, which is the opposite of the lagged REER coefficient's sign. It can be inferred that there may possibly be an adverse effect of the level of integration with GVC on the exchange rate elasticity of exports.

For the estimation with the GVC participation index (column (1)), the predicted REER elasticity of exports is 0.5730. The participation in the GVC reduces the exchange rate elasticity of exports by $88.14 \%$. Looking at the estimation result in column (3), it can be calculated that the exchange rate elasticity of exports is 0.7056 . The number also shows that the presence of foreign value-added causes a decline in exchange rate elasticity of exports by $89.04 \%$.

A different result is found when the GVC position index is included in the model (column (2)). The signs of the coefficient of exchange rate variable and the interaction term between exchange rate and GVC position index are the same. However, as displayed in the Table 4, the average value of the GVC position index is -0.2167 . The negative sign indicates that the position of the Malaysian industry is in the downstream part of GVC. Hence, the REER elasticity of exports will lower by $70.68 \%$ when the GVC position index is considered.

\section{The Philippines}

In the case of the Philippines, regression results in Table 5 show the sign of the estimated REER elasticity of exports is consistent with the hypothesis in the estimation with the GVC participation index (column (1)). However, the coefficients are not statistically significant. In the regression with the GVC participation index and with foreign value-added shares, it can be seen that the coefficient of the lagged value of industry-specific REER and the coefficient of the interaction term has an opposite sign. Although they are not statistically significant, this may indicate that the presence of GVC may weaken the exchange rate elasticity of exports.

The result may relate to the fact that the Philippines' involvement in GVC has been decreasing since 2010 (ASEAN-Japan Centre, 2017b). According to the report, this phenomenon happened because of several reasons. First, the amount of FDI is not sufficient to create GVC. Second, they used the FDI for importsubstitution policy. Third, the structure of economy has started to move toward services sector which requires less foreign value-added. 
Table 5. Regression Results for the Philippines

\begin{tabular}{|c|c|c|c|}
\hline Dependent Variable: Export Volume & $\begin{array}{c}\text { (1) } \\
\text { With GVC } \\
\text { participation } \\
\text { index }\end{array}$ & $\begin{array}{c}(2) \\
\text { With GVC } \\
\text { position } \\
\text { Index }\end{array}$ & $\begin{array}{c}\text { (3) } \\
\text { With foreign } \\
\text { value-added } \\
\text { shares }\end{array}$ \\
\hline Lagged Industry-Specific REER & $\begin{array}{l}-0.9646 \\
{[2.0097]}\end{array}$ & $\begin{array}{c}0.3741 \\
{[1.0122]}\end{array}$ & $\begin{array}{c}0.7607 \\
{[2.2440]}\end{array}$ \\
\hline Lagged Foreign Output & $\begin{array}{c}0.0352 \\
{[1.1422]}\end{array}$ & $\begin{array}{c}1.1708 \\
{[1.1943]}\end{array}$ & $\begin{array}{c}1.4586 \\
{[1.3254]}\end{array}$ \\
\hline Lagged Real Output & $\begin{array}{c}0.2557 \\
{[0.4540]}\end{array}$ & $\begin{array}{c}0.1481 \\
{[0.4256]}\end{array}$ & $\begin{array}{l}-0.0610 \\
{[0.4539]}\end{array}$ \\
\hline Lagged GVC Participation Index & $\begin{array}{c}1.3199 \\
{[1.4249]}\end{array}$ & & \\
\hline $\begin{array}{l}\text { Interaction between Lagged REER and Lagged } \\
\text { GVC Participation Index }\end{array}$ & $\begin{array}{c}1.8200 \\
{[4.8355]}\end{array}$ & & \\
\hline Lagged GVC Position Index & & $\begin{array}{l}3.5290^{* *} \\
{[1.5391]}\end{array}$ & \\
\hline $\begin{array}{l}\text { Interaction between Lagged REER and Lagged } \\
\text { GVC Position Index }\end{array}$ & & $\begin{array}{l}12.7478 \\
{[9.3024]}\end{array}$ & \\
\hline Lagged Foreign Value Added (FVA) & & & $\begin{array}{l}-5.8142^{*} \\
{[3.1375]}\end{array}$ \\
\hline $\begin{array}{l}\text { Interaction between lagged REER and lagged } \\
\text { FVA }\end{array}$ & & & $\begin{array}{l}-6.7554 \\
{[8.6885]}\end{array}$ \\
\hline Constant & $\begin{array}{l}-1.9391 \\
{[2.8537]}\end{array}$ & $\begin{array}{l}-1.1156 \\
{[2.6202]}\end{array}$ & $\begin{array}{c}0.6027 \\
{[2.8610]}\end{array}$ \\
\hline Industry Fixed Effects & Yes & Yes & Yes \\
\hline Year Fixed Effects & Yes & Yes & Yes \\
\hline $\begin{array}{l}\text { Observations } \\
\text { R-squared }\end{array}$ & $\begin{array}{c}78 \\
0.2818 \\
\end{array}$ & $\begin{array}{c}78 \\
0.3464 \\
\end{array}$ & $\begin{array}{c}78 \\
0.3183 \\
\end{array}$ \\
\hline
\end{tabular}

Standard errors in brackets

${ }^{*} p<0.10,{ }^{* *} p<0.05,{ }^{* * *} p<0.01$

\section{Thailand}

The results in Table 6 indicate that, when the GVC variables are included in the model, the sign of the lagged REER variable is positive. Conversely, the coefficients of the interaction variables in column (1) and column (3) have negative signs. The coefficients of lagged REER and the interaction term are only significant in column (1). We found that REER elasticity of exports is -1.3880 . The presence of GVC changes the REER elasticity of exchange by $122.57 \%$ and reverses the sign from positive to negative.
Based on ASEAN-Japan Centre Report (2019), trade liberalization and increase in FDI has successfully helped Thailand to upgrade the industry from low-tech to mid-tech industries. With a solid improvement in automotive and electrical industries has allowed Thailand to enjoy the advantage of participation in global market. Therefore, association in GVC may have a quite significant impact to the exchange rate elasticity of export.

In the results of the estimation in column (2), the coefficient of the lagged REER and interaction variable between the lagged REER and lagged GVC 
position index exhibits the same positive sign. However, none of the coefficients are statistically significant. Hence, the magnitude of the effects of position in GVC to REER elasticity of exports cannot be calculated.

Table 6. Regression Results for Thailand

\begin{tabular}{lccc}
\hline $\begin{array}{l}\text { Dependent Variable: } \\
\text { Export Volume }\end{array}$ & $\begin{array}{c}\text { With GVC } \\
\text { participation index }\end{array}$ & $\begin{array}{c}\text { With GVC position } \\
\text { Index }\end{array}$ & $\begin{array}{c}(\mathbf{2}) \\
\text { With foreign value- } \\
\text { added shares }\end{array}$ \\
\hline Lagged Industry-Specific & $6.1499^{* *}$ & 1.2198 & 3.6745 \\
REER & {$[2.6719]$} & {$[2.3150]$} & {$[2.4268]$} \\
Lagged Foreign Output & 3.4378 & 2.2682 & 3.1518 \\
& {$[2.9111]$} & {$[2.4166]$} & {$[2.7032]$} \\
Lagged Real Output & 0.4127 & 0.9653 & 0.6795 \\
& {$[0.9598]$} & {$[1.1436]$} & {$[1.0477]$} \\
Lagged GVC Participation & -1.3609 & & \\
Index & {$[2.5199]$} & & \\
Interaction between Lagged & $-15.0638^{* *}$ & & \\
REER and Lagged GVC & {$[6.6484]$} & & \\
Participation Index & & & \\
Lagged GVC Position Index & & $6.1381^{* *}$ & \\
& & {$[3.0356]$} & \\
Interaction between Lagged & & 10.6524 & \\
REER and Lagged GVC & & {$[8.8381]$} & \\
Position Index & & & -4.4160 \\
Lagged Foreign Value & & & {$[2.9214]$} \\
Added (FVA) & & & $-12.9783^{*}$ \\
Interaction between lagged & & & -3.8639 \\
REER and lagged FVA & & & {$[6.7697]$} \\
Constant & -2.6005 & -5.7607 & Yes \\
Industry Fixed Effects & {$[6.2894]$} & {$[7.4699]$} & Yes \\
Year Fixed Effects & Yes & Yes & 78 \\
\hline Observations & Yes & 78 & 0.3729 \\
R-squared & 78 & & \\
\hline
\end{tabular}

Heteroscedasticity robust standard errors in brackets

${ }^{*} p<0.10,{ }^{* *} p<0.05,{ }^{* * *} p<0.01$

\section{Group of Four ASEAN Countries}

After running the estimation for each country, this study also assesses the effects of GVC on the exchange rate elasticity of exports in the group of four ASEAN countries. The purpose of this estimation is to see whether the results of the individual entity and the group will be the same. As presented in Table 7, the output in columns (1) and (2) show that the coefficients on the exchange rate variable and the interaction terms are not statistically significant.

The coefficient of the exchange rate is statistically significant in the regression with foreign value-added shares (column (3)). The expected REER elasticity of exports is -0.3078 . 
Since the sign of the coefficient of the lagged industry-specific REER is positive while the sign of the coefficient of the interaction term between the lagged REER and lagged FVA is negative, the presence of foreign valueadded shares in the four ASEAN countries changes the REER elasticity of exports by $113.21 \%$. The inclusion of
FVA in the model changes not only the magnitude of elasticity but also the sign from positive to negative. The negative sign is consistent with the theory and suggests that if there is a $1 \%$ depreciation (decrease) in REER, the growth of export volume will increase by $0.31 \%$, ceteris paribus.

Table 7. Regression Result for Four ASEAN Countries

\begin{tabular}{|c|c|c|c|}
\hline Dependent Variable: Export Volume & $\begin{array}{c}\text { (1) } \\
\text { With GVC } \\
\text { participation } \\
\text { index }\end{array}$ & $\begin{array}{c}\text { (2) } \\
\text { With GVC } \\
\text { position } \\
\text { Index }\end{array}$ & $\begin{array}{c}\text { (3) } \\
\text { With foreign } \\
\text { value-added } \\
\text { shares }\end{array}$ \\
\hline Lagged Industry-Specific REER & $\begin{array}{c}1.1102 \\
{[0.8321]}\end{array}$ & $\begin{array}{c}0.4483 \\
{[0.3344]}\end{array}$ & $\begin{array}{l}2.3295^{* *} \\
{[0.9219]}\end{array}$ \\
\hline Lagged Foreign Output & $\begin{array}{c}0.6526 \\
{[0.6009]}\end{array}$ & $\begin{array}{c}0.9407 \\
{[0.6550]}\end{array}$ & $\begin{array}{c}1.0463 \\
{[0.6696]}\end{array}$ \\
\hline Lagged Real Output & $\begin{array}{c}0.0242 \\
{[0.0181]}\end{array}$ & $\begin{array}{c}0.0187 \\
{[0.0169]}\end{array}$ & $\begin{array}{c}0.0162 \\
{[0.0179]}\end{array}$ \\
\hline Lagged GVC Participation Index & $\begin{array}{c}0.1368 \\
{[0.1730]}\end{array}$ & & \\
\hline $\begin{array}{l}\text { Interaction between Lagged REER and } \\
\text { Lagged GVC Participation Index }\end{array}$ & $\begin{array}{l}-3.1750 \\
{[2.0897]}\end{array}$ & & \\
\hline Lagged GVC Position Index & & $\begin{array}{c}0.0371 \\
{[0.2444]}\end{array}$ & \\
\hline $\begin{array}{l}\text { Interaction between Lagged REER and } \\
\text { Lagged GVC Position Index }\end{array}$ & & $\begin{array}{l}5.1800^{* *} \\
{[2.0199]}\end{array}$ & \\
\hline Lagged Foreign Value Added (FVA) & & & $\begin{array}{c}0.0442 \\
{[0.2116]}\end{array}$ \\
\hline $\begin{array}{l}\text { Interaction between Lagged REER and } \\
\text { Lagged FVA }\end{array}$ & & & $\begin{array}{l}-8.4392^{\star * *} \\
{[3.1085]}\end{array}$ \\
\hline Constant & $\begin{array}{l}-0.1551 \\
{[0.1343]}\end{array}$ & $\begin{array}{l}-0.1088 \\
{[0.1228]}\end{array}$ & $\begin{array}{l}-0.0911 \\
{[0.1315]}\end{array}$ \\
\hline Industry Fixed Effects & Yes & Yes & Yes \\
\hline Year Fixed Effects & Yes & Yes & Yes \\
\hline $\begin{array}{l}\text { Observations } \\
\text { R-squared }\end{array}$ & $\begin{array}{c}312 \\
0.0998\end{array}$ & $\begin{array}{c}312 \\
0.1059\end{array}$ & $\begin{array}{c}312 \\
0.1226 \\
\end{array}$ \\
\hline
\end{tabular}

Heteroscedasticity robust standard errors in brackets

${ }^{*} p<0.10,{ }^{* *} p<0.05,{ }^{* * *} p<0.01$

CONCLUSION AND POLICY research focused on the value and sign RECOMMENDATION

To examine the effects of GVC on the REER elasticity of exports, this of two parameters. First is the coefficient of the lagged REER variable or exchange rate elasticity of exports $(\beta)$. 
The second one is the coefficient of the interaction term between the lagged GVC and lagged REER $(\tau)$.

Looking into the detail of the estimation output of each country, the parameters $\beta$ and $\tau$ in the Philippines' regression are not statistically significant. Therefore, how the GVC impacts the exchange rate elasticity of exports cannot be measured for this country. For the case of Indonesia, the estimated REER elasticity of exports has a negative sign, which is consistent with the hypothesis. When the GVC is measured by the GVC participation index, the estimated exchange rate elasticity of exports will be reduced by $80.10 \%$. Also, on average, integration in GVC measured by the shares of foreign inputs to gross exports will lower the REER elasticity of exports in Indonesia by $88.75 \%$.

The regression results from Malaysia indicate that the REER elasticity of exports has a positive sign, which is contradictory to the prediction. Integrations with GVC, which are measured by the GVC participation index, GVC position index, and foreign value-added shares, weaken the elasticity by $88.14 \%, 70.68 \%$, and $89.04 \%$, respectively.
The different signs of exchange rate elasticity of exports in Indonesia and Malaysia may be attributed to the differences in their decomposition of value-added exports. Domestic valueadded shares in Indonesia have a more substantial proportion than that of Malaysia. Hence, a depreciation of the exchange rate will improve the competitiveness of Indonesian exported goods. On the contrary, since Malaysia relies more on imported intermediate inputs, depreciation may raise the production cost and decrease the competitiveness of its products.

Lastly, in the estimation results of Thailand and the four countries, it was found that integration with GVC reversed the sign of the estimated REER elasticity of exports. The expected exchange rate elasticity of exports in Thailand and the group of four ASEAN countries were $\quad-1.388$ and -0.3078 , respectively. Hence, the depreciation of the exchange rate will improve the export performance of this group of countries.

Since the presence of GVC will affect the sensitivity of exports to changes in the exchange rate, designing an appropriate policy related to exports can be more challenging. Depreciation of exchange rates is not enough to boost 
exports; nevertheless, improvement on the competitiveness of the exported products is also essential. Better competitiveness will create more chance for the country to engage more in the value chain productions. To enhance participation in GVC, countries also need to improve investment climate to attract more FDI. Hence, it can reap more benefit from the participation of global supply chain.

The differences in the impact of GVC to REER elasticity of export in four ASEAN countries also indicate the economic divergence in this region. As mentioned in Lu Xu et al. (2007), exchange rates are among the three factors that affect the economic convergence. Hence, the results of this study may support the conclusions of previous research that ASEAN needs to work harder if they want to reach economic integration and to form a currency union.

One of the limitations of this study is it cannot address the pure doublecounting problem during the decomposition of gross exports into GVC components. Solving this issue will produce better empirical work in the future. Finally, future research may also examine this topic by using more detailed firm-level data, if available, or by including analysis for primary and service sectors.

\section{ACKNOWLEDGEMENT}

The authors thank the Ministry of National Development Planning/ National Development Planning Agency (Bappenas) and Japan International Cooperation Agency (JICA) Scholarship for the support and sponsorship of the Indonesia Linkage Program between the University of Indonesia and Yokohama National University. The authors want to deliver sincere gratitude to Professor Craig Robert Parsons, for his valuable advice on the empirical part of this research.

\section{REFERENCES}

Abeysinghe, T., \& Yeok, T. (1998). Exchange Rate Appreciation and Export Competitiveness. The Case of Singapore. Applied Economics, 30(1), 51-55.

Ahmad, N., Bohn, T., Mulder, N., Vaillant, M., \& Zaclicever, D. (2017). Indicators on Global Value Chains: A Guide for Empirical Work. OECD Statistics Working Papers 2017/8.

Ahmed, S., Appendino, M., \& Ruta, M. (2016). Global Value Chains and the Exchange Rate Elasticity of Exports. The B.E. Journal of Macroeconomics, 17(1), 1-24. https://doi.org/10.1515/bejm-20150130.

Amador, J., \& Cabral, S. (2016). Global Value Chains: A Survey of Drivers and Measures. Journal of Economic Surveys, 30(2), 278-301.

Amiti, M., Itskhoki, O., \& Konings, J. (2014). Importers, Exporters, and Exchange 
Rate Disconnect. American Economic Review, 104(7), 1942-1978. https://doi.org/10.1257/aer.104.7.194 2.

ASEAN Secretariat. (2019). ASEAN Integration Report 2019. Jakarta.

ASEAN-Japan Centre. (2017a, September). Retrieved January 29, 2019, from Global Value Chains in ASEAN: A Regional Perspective: https://www.asean.or.jp/ja/wpcontent/uploads/sites/2/2017/08/GVC -in-ASEAN_paper-1_A-RegionalPerspective.pdf

ASEAN-Japan Centre. (2017b, July). Retrieved March 2, 2021, from Global Value Chains in ASEAN: The Philippines:

https://www.asean.or.jp/en/centrewide-info/gvc database paper8/

ASEAN-Japan Centre. (2018, August). Retrieved March 3, 2021, from Global Value Chains in ASEAN: Thailand:https://www.asean.or.jp/en/ centre-wideinfo/gvc_database_paper9/

ASEAN-Japan Centre. (2019, March). Retrieved March 1, 2021, from Global Value Chains in ASEAN: Thailand:https://www.asean.or.jp/en/ centre-wideinfo/gvc_database_paper10/

Aslam, A., Novta, N., \& Rodrigues-Bastos, F. (2017). Calculating Trade in Value Added. IMF Working Paper $W P / 17 / 178$.

Bang, H., \& Park, M. (2018). Global Value Chain and Its Impact on the Linkage between Exchange Rate and Export: Cases of China, Japan and Korea. World Economy, 41(9), 2552-2576. https://doi.org/10.1111/twec.12595

Cheng, K. C., Hong, G., Seneviratne, D., \& van Elkan, R. (2016). Rethinking the Exchange Rate Impact on Trade in a World with Global Value Chains. International Economic Journal, 30(2), 204-216. https://doi.org/10.1080/10168737.201 6.1148418 . de Soyres, F., Frohm, E., Gunnella, V., \& Pavlova, E. (2018). Bought, Sold and Bought Again: The Impact of Complex Value Chains on Export Elasticities. Policy Research Working Paper 8535.

Dedrick, J., Kraemer, K., \& Linden, G. (2010). Who Profits from Innovation in Global Value Chains? A Study of the iPod and Notebook PCs. Industrial and Corporate Change, 19(1), 81116.

Fauceglia, D., Lassmann, A., Shingal, A., \& Wermelinger, M. (2018). Backward Participation in Global Value Chains and Exchange Rate Driven Adjustments of Swiss Exports. Review of World Economics, 154(3), 537-584.

Giugliano, F. (2015, March 9). Rich Economies Question Faith in Power of Lower Exchange Rates. Retrieved January 23, 2019, from Financial Times:

https://www.ft.com/content/b87a0e98 -c426-11e4-9019-00144feab7de

IMF. (n.d.). What is Real Effective Exchange Rate (REER)? Retrieved from

http://datahelp.imf.org/knowledgebas e/articles/537472-what-is-realeffective-exchange-rate-reer

Investing.com. (2020). Retrieved from https://www.investing.com/currencies

Kang, J. W., \& Dagli, S. (2018). International Trade and Exchange Rates. Journal of Applied Economics, 21(1), 84-105.

Koopman, R., Powers, W., Wang, Z., \& Wei, S.-J. (2010). Give Credit Where Credit Is Due: Tracing Value Added in Global Production Chains. NBER Working Paper No. 16426.

Koopman, R., Wang, Z., \& Wei, S.-J. (2014). Tracing Value-Added and Double Counting in Gross Exports. American Economic Review, 104(2), 459-494.

Krugman, P. R., Obstfeld, M., \& Melitz, M. (2015). International Economics: 
Theory \& Policy, Tenth Edition. Pearson Education, Inc.

Leigh, D., Lian, W., Poplawski-Ribeiro, M., Tsyrennikov, V. (2015). Exchange Rates and Trade Flows: Disconnected? In World Economic Outlook: Adjusting to Lower Commodity Prices. IMF.

Lu Xu, Z., Ward, B. D., \& Gan, C. (2007). Chapter 6 A Single Currency for ASEAN-5: An Empirical Study of Economic Convergence and Symmetry. In S.-J. Kim, \& M. D. McKenzie, Asia-Pacific Financial Markets: Integration, Innovation and Challenges (International Finance Review, Vol. 8) (pp. 117 - 139). Emerald Group Publishing Limited.

Mallick, S., \& Marques, H. (2016). Does Quality Differentiation Matter in Exporters' Pricing Behaviour? Comparing China and India. China Economic Review, 40, 71-90. https://doi.org/10.1016/j.chieco.2016. 06.001.

Obstfeld, M., \& Rogoff, K. (2007). The Unsustainable U.S. Current Account Position Revisited. In R. H. Clarida, G7 Current Account Imbalances: Sustainability and Adjustment (pp. 339 - 376). University of Chicago Press.

OECD. (2018a, December). HS to ISIC to End-use Conversion Key. Retrieved January 28, 2019, from http://stats.oecd.org/wbos/fileview2.a spx?IDFile=2bddcb44-5e74-49a08 8ac980ed46a2274c\&_ga=2.46693991.13 15308799.1548653389-

1281714744.1545622259

OECD. (2018b, December). OECD InterCountry Input-Output (ICIO) Tables. Retrieved January 28, 2019, from http://www.oecd.org/sti/ind/intercountry-input-output-tables.htm

OECD TiVA Database. (2020, June). Trade in Value Added (TiVA): Principal indicators. Retrieved from
https://stats.oecd.org/Index.aspx?dat asetcode=TIVA_2018_C1

Ollivaud, P., Rusticelli, E., \& Schwellnus, C. (2015). The Changing Role of the Exchange Rate for Macroeconomic Adjustment. OECD Economics Department Working Paper 1190.

RIETI. (n.d.). Industry-Specific Nominal and Real Effective Exchange Rates of 25 Countries Worldwide. Retrieved from https://www.rieti.go.jp/users/eeri/en/

Sato, K., \& Zhang, S. (2019). Do Exchange Rates Matter in Global Value Chains? RIETI Discussion Paper Series 19-E059.

Sato, K., Shimizu, J., Shrestha, N., \& Zhang, S. (2015). Industry-specific Real Effective Exchange Rates in Asia. RIETI Discussion Paper Series 15-E-036.

Sato, K., Shimizu, J., Shrestha, N., \& Zhang, S. (2016). Industry-Specific Exchange Rate Volatility and Intermediate Goods Trade in Asia. Scottish Journal of Political Economy, 63(1), 89-109. https://doi.org/10.1111/sjpe.12112.

Soejachmoen, M. P. (2016). Globalization of the Automotive Industry: Is IndonesiaMissing Out? Asian Economic Papers, 15(1), 1-19.

Tan, K. G., Duong, L., \& Chuah, H. (2019). Impact of Exchange Rates on ASEAN's Trade in The Era of Global Value Chains: An Empirical Assessment. The Journal of International Trade \& Economic Development, 28(7), 873-901.

Timmer, M. P., Erumban, A., Los, B., Stehrer, R., \& de Vries, G. (2014). Slicing Up Global Value Chains. Journal of Economic Perspectives, 28(2), 99-118.

Trade Map. (n.d.). Trade Statistics for International Business Development. Retrieved from Trade Map: https://www.trademap.org/Index.aspx 
UN Comtrade. (2020). UN Comtrade Database. Retrieved from https://comtrade.un.org/

UN Trade Statistics. (2020, June). Harmonized Commodity Description and Coding Systems (HS). Retrieved from

https://unstats.un.org/unsd/tradekb/K nowledgebase/50018/Harmonized-

Commodity-Description-and-CodingSystems-HS

UNCTAD. (2013). Global Value Chains and Development: Investment and Value Added Trade in the Global Economy. United Nations.

UNCTAD. (2019). Key Statistics and Trends in International Trade 2018. Geneva: United Nations.

United Nations Statistics Division. (n.d.). International Standard Industrial Classification of All Economic Activities Revision 4. Retrieved from https://unstats.un.org/unsd/classificati ons/Econ/Download/In\%20Text/ISIC _Rev_4_publication_English.pdf
Williams, R. (2015, February 20). Interaction effects between continuous variables (Optional). Retrieved from https://www3.nd.edu/ rwilliam/stats2/ 155.pdf

WITS. (2020). World Integrated Trade Solution (WITS). Retrieved from https://wits.worldbank.org/

World Bank. (2020, June). Exports of goods and services (current US\$). Retrieved from

https://data.worldbank.org/indicator/N E.EXP.GNFS.CD

World Bank Group; IDE-JETRO; OECD; UIBE; World Trade Organization. (2017). Global Value Chain Development Report 2017:Measuring and Analysing the Impact of GVCs on Economic Development. Washington DC: World Bank. Retrieved from https://www.wto.org/english/res_e/bo oksp_e/gvcs_report_2017.pdf 